\title{
РОЛЬ ПІСЛЯДИПЛОМНОГО НАВЧАННЯ В ПРОФІЛАКТИЦІ СИНДРОМУ ЕМОЦІЙНОГО ВИГОРАННЯ У ЛІКАРІВ ПЕРВИННОЇ ЛАНКИ
}

\section{T. B. Lazarchuk, O. Y. Samogalska, I. V. Meretska \\ I. Horbachevsky Ternopil State Medical University \\ THE ROLE OF POSTGRADUTE TRAINING IN THE PREVENTION OF BURNOUT SYNDROME IN PRIMARY CARE PHYSICIANS}

\begin{abstract}
Анотація. Анонімне анкетування 223 слухачів передатестаційних циклів (ПАЦ) у 2018 р. виявило високу частоту формування СЕВ у лікарів ПМД із найвищим показником серед лікарів медицини невідкладних станів (МНС). У рейтинговій структурі стресорів для лікарів МНС на першому місці була низька зарплатня - $(5,42 \pm 1,2)$ бала; у сімейних лікарів і терапевтів - надлишок бюрократичних завдань - $(6,78 \pm 2,2)$ та $(6,22 \pm 3,2)$ бала відповідно. Перевагу у подоланні СЕВ 67,6 \% лікарів ПМД надають обговоренню проблеми в сімейному або дружньому колі; фізичні навантаження, як засіб подолання стресу, обирали 41,9 \%. Опитування за методикою В. Бойка виявило формування фази резистенції у 87,2 \% респондентів із домінуючим симптомом «розширення сфери «економії» емоцій» - $(30,2 \pm 10,4)$ бала. Відповіді на блок запитань, щодо мотиваційних факторів навчання на ПАЦ, а також його ролі у подоланні СЕВ, продемонстрували схильність більшості слухачів вважати зростання професійного рівня профілактичним чинником подолання СЕВ у сучасних умовах. Отже, післядипломну освіту можна розглядати як чинник підвищення ефективності комплексу превентивних заходів для подолання СЕВ у лікарів ПМД.
\end{abstract}

Ключові слова: емоційне вигорання; лікарі; профілактика; післядипломна освіта.

Abstract. An anonymous questionnaire for 223 listeners of pre-certification cycles in 2018 revealed a high incidence rate of burnout syndrome among primary health care physicians with the highest rates among emergency medicine doctors. In the rating structure of stressors for emergency medicine doctors in the first place was a low salary - (5.42 \pm 1.2$)$ points; in family doctors and physicians excess of bureaucratic tasks - (6.78 \pm 2.2$)$ and (6.22 \pm 3.2$)$ points, respectively. Advantage in overcoming the burnout syndrome $67.6 \%$ of primary health care physicians provide a discussion in the family or circle of friends; exercise, as a means of overcoming stress, was selected by $41.9 \%$. The survey by the technique of Boyko V. revealed the formation of a resistence phase in $87.2 \%$ of respondents with a dominant symptom "expanding the scope of "saving"emotions" - (30.2 \pm 10.4$)$ points. Answers to the block of questions, about the motivational factors of training in pre-certification courses, as well as its role in overcoming the burnout syndrome, demonstrated the tendency of most listeners to consider the growth of professional level as a preventative factor in overcoming the syndrome in modern conditions. Therefore, postgraduate training can be considered as a factor in increasing the effectiveness of a complex of preventive measures to overcome the burnout syndrome in primary care doctors.

Key words: burnout syndrome; doctors; prevention; postgraduate training.

Вступ. Інтенсифікація життя, соціально-політичні та соціально-економічні процеси, що відбуваються в Україні нині, висувають до працівників

(c) Т. Б. Лазарчук, О. Є. Самогальська, I. В. Мерецька гуманітарної сфери, у т. ч. медичної, нові, більш складні та водночас недостатньо структуровані вимоги. Відповідальність за людські життя та здоров’я, активна міжособистісна взаємодія, не- 
достатня соціальна оцінка, низький рівень оплати у поєднанні із факторами особистого фізичного, психологічного, соціального здоров’я створюють атмосферу постійного емоційного напруження i, як наслідок, розвиток синдрому емоційного виснаження (CEB) $[1,4,5]$. За словами Уляни Супрун, «в Україні система охорони здоров'я знаходиться у катастрофічному стані і реорганізація їі тільки розпочалася, тому зрозуміло, що однією з суттєвих причин емоційного вигорання українських медиків є низький рівень оплати праці» [4]. Важливим у розумінні СЕВ є те, що «на відміну від депресії, вигорання не $є$ хворобою» [5, 7]. Тому раціонально організований, різноплановий підхід до профілактики та превенції СЕВ здатний покращити стресостійкість лікарів і, як наслідок, якість медичної допомоги.

Мета статті - визначити основні професійні стресори у лікарів первинної медичної допомоги (ПМД) закладів охорони здоров'я міста Тернополя та Тернопільської області, виміряти реакцію на них та з'ясувати місце і роль післядипломного навчання в профілактиці СЕВ.

Теоретична частина. Усім слухачам під час реєстрації на передатестаційні цикли (ПАЦ) пропонувалося анонімне анкетування, що включало блок запитань, запозичених у щорічному звіті «Medscape National Physician Burnout \& Depression Report 2018» [6], стосовно факторів СЕВ та шляхів його подолання; а також запитання діагностичної анкети В. Бойка, що складається із 84 тверджень, до кожного з яких респондент повинен був висловити своє ставлення у вигляді однозначної відповіді «так» чи «ні». Методика дає докладну картину CEB, акцентуючи увагу як на окремих симптомах, так і на показниках фаз розвитку стресу - «напруга», «резистенція» та «виснаження», створюючи уявлення про те, наскільки сформована та чи інша фаза. Сума балів менше 9 свідчила про відсутність симптому; 10-15 балів - про формування симптому; 16-20 балів - про сформований симптом. Наступним кроком була оцінка формування кожної із фаз: менше 36 балів - фаза не сформувалася; 37-60 балів - фаза на стадії формування; 61 і більше балів - сформована фаза із виокремленням домінуючого симптому [2].

В опитуванні взяли участь 223 слухачі ПАЦ у 2018 р. Із 223 анкет 23 відхилено як некоректно заповнені. Відтак проаналізовано 200 анкет, на запитання яких відповіли 30 лікарів медицини невідкладних станів (MHC), 111 лікарів загальної практики - сімейної медицини (ЗПСМ) та 59 те- рапевтів. Середній вік респондентів становив $(47,54 \pm 8,21)$ року, при цьому чоловіки були достовірно старшими за жінок - відповідно, $(57,33 \pm 17,7)$ i $(47,96 \pm 12,4)$ року, $(\mathrm{p}<0,05)$. Співвідношення жінки/чоловіки становило 2,8/1. Середній стаж роботи - $(12,9 \pm 7,6)$ року.

Отримані результати опрацювали з використанням статистичної програми Microsoft Excel.

Про емоційну втому повідомили 76,7 \% лікарів MHC, 43,2 \% лікарів 3ПСМ, 61 \% дільничних терапевтів. Із них ознаки субклінічної депресії (СКД) запідозрили в себе 23,4 \% сімейних лікарів, 3 лікарі MHC (10 \%), 15,3 \% терапевтів. Більшість лікарів MHC (86,7 \%), а також 66,7 \% і 65 \% відповідно сімейних лікарів та терапевтів усвідомлюють порушення в психоемоційній сфері. При цьому частка жінок була вищою - 3,1/1. Більш чутливими до психоемоційного тиску виявилися лікарі середнього віку (45-54 роки), саме вони найчастіше повідомляли про СЕВ або СКД - 87,3 \%. За бальною шкалою (від 1 (рідко) до 7 (часто)) частота епізодів емоційної втоми у 45 \% респондентів сягала 5, у $32 \%$ - 3 та у $12 \%$ - 1 бала. У 88,9 \% лікарів МНС на розвиток СЕВ частіше і сильніше впливала низька зарплатня - $(5,42 \pm 1,2)$ бала; у 55,6 \% - надлишок бюрократичних завдань $(3,71 \pm 1,9)$ бала; у 55,6 \% - ненормований режим роботи - $(3,99 \pm 0,5)$ бала. У 67,4 \% сімейних лікарів та 71,6 \% терапевтів перше рейтингове місце посідає «надлишок бюрократичних завдань» $(6,78 \pm 2,2)$ та $(6,22 \pm 3,2)$ бала відповідно. Низька зарплатня турбує 60,5 \% лікарів 3ПСМ - $(4,42 \pm 2,4)$ бала та 43,2 \% терапевтів - $(4,44 \pm 0,9)$ бала. Ненормований режим роботи як фактор стресу вказали

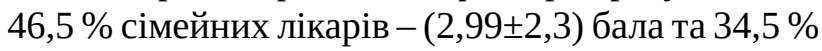
терапевтів - $(2,01 \pm 0,1)$ бала. Респонденти, які зазначили високу частоту повторюваних епізодів виснаження ( $\geq 5$ балів), а це 18,2 \% респондентів, як правило, вказували на більше ніж два фактори. Примітно, що тільки 32,8 \% усіх опитаних відповіли, що пригнічений настрій не впливає на ставлення до пацієнтів; 33,5 \% лікарів ПМД зазначили, що у періоди СЕВ спілкування з пацієнтами легко дратує і порушує взаєморозуміння із ними; 28,6 \% приділяють менше часу спілкуванню із пацієнтами, а у 5,1 \% - призводить до помилок.

Для подолання СЕВ 67,6 \% лікарів перевагу надають обговоренню проблеми в сімейному або дружньому колі; фізичні навантаження, як засіб подолання стресу, обирали 41,9 \%; вдавалися до усамітнення 20,3 \%; на тютюнокуріння та вживання алкогольних напоїв вказували переважно 
чоловіки - 16,2 \%; 15,4 \% жінок-лікарів використовували заспокійливі засоби та тамували стрес їдою. Професійною психотерапевтичною допомогою скористалися 22,2 \% лікарів із ознаками СЕВ, четверо із них продовжували прийом ліків і на час опитування.

За результатами аналізу 150 анкет В. Бойка, хронічна психоемоційна атмосфера, нестабільні, загострені обставини, підвищена відповідальність, незадовільна взаємодія з оточуючими зумовлювали розвиток напруження у $58,2 \%$ осіб із усередненими домінуючим симптомом «переживання психотравмуючих обставин» - $(24,1 \pm 7,3)$ бала; сформованими симптомами «тривоги і депресії» - $(19,7 \pm 6,0)$ бала та «загнаності у клітку» - $(15,4 \pm 3,6)$ бала. Намагання відгородитися від неприємних вражень, зовнішніх впливів зумовили формування симптомів резистенції у 87,2 \% респондентів із домінуванням за усередненими показниками «розширення сфери «економії» емоцій» - $(30,2 \pm 10,4)$ бала та сформованим симптомом «неадекватного емоційного вибіркового реагування» - $(24,2 \pm 8,0)$ бала. Примітно, що прояви «емоційно-моральної дезорієнтації» не були властивими респондентам за будь-яких обставин. Ознаки формування фази виснаження зареєстрували у 45,5 \% осіб із формуванням домінуючого симптому у 10 респондентів переважно у вигляді деперсоналізації та психосоматичних/ вегетативних порушень.

Анонімне анкетування в останній день навчання на ПАЦ передбачало відповіді на блок запитань для визначення мотиваційних факторів щодо післядипломного навчання, якості та корисності отриманої інформації, доповнене запитанням «Чи вважаєте Ви, що зростання професійного рівня є профілактикою емоційного вигорання в сучасних умовах?» [3]. Аналіз 104 анкет виявив, що для 87 респон-

\section{Список літератури}

1. Булах В. П. Синдром професійного вигорання як складний патофізіологічний феномен / В. П. Булах // Медсестринство. - 2015. - № 4. - С. 47-51.

2. Райгородский Д. Я. Практическая психодиагностика. Методики и тесты : уч. пос. / Д. Я. Райгородский. - Самара : Издательский дом «БАХРАХ-М», 2005. - 672 с.

3. Юрьева Л. М. Профессиональное выгорание у медицинских работников: формирование, профилактика, коррекция : монография / Л. М. Юрьева. - К. : Сфера, 2004. - 272 c.

4. Як впоратись з емоційним вигоранням медичним працівникам [Електронний ресурс] / MOЗ України. http://moz.gov.ua/article/for-medical-staff/jak-vporitis-zemocijnim-vigorannjam-medichnim-pracivnikam. дентів (83,7 \%) навчання на ПАЦ є можливістю отримати нову інформацію, яку планують використовувати у своїй практиці (90,8 \%), та одночасно можливістю відпочити. Примітно, що навчання на ПАЦ як необхідність для покращення своєї роботи (і матеріального становища) розглядали лише 20,2 \% респондентів, переважно молодого віку, а на запитання «Чи вважаєте Ви, що зростання професійного рівня $є$ профілактикою емоційного вигорання в сучасних умовах?» позитивно відповіли 59 (56,7 \%) респондентів.

Висновки та перспективи подальших досліджень. Для більшості лікарів ПМД (60,3 \%) притаманний СЕВ із домінуючим симптомом «розширення сфери «економії» емоцій» - $(30,2 \pm 10,4)$ бала. Основними причинами СЕВ лікарі ПМД назвали низьку зарплатню, надлишок бюрократичних завдань та ненормований робочий день. Для подолання СЕВ 67,6 \% лікарів ПМД обирають спілкування в сім'ї та дружньому колі. Навчання на ПАЦ 83,7 \% лікарів ПМД оцінюють як можливість одночасно отримати нову інформацію та відпочити, вважаючи при цьому, що зростання професійного рівня $\epsilon$ профілактичним заходом емоційного вигорання в сучасних умовах. Отже, післядипломну освіту можна розглядати як чинник підвищення ефективності комплексу превентивних заходів для подолання СЕВ у лікарів ПМД.

3 урахуванням отриманих результатів вважаємо перспективним розробку і впровадження у навчальний процес, особливо на етапі первинної спеціалізації, курсу конфліктології з метою формування у майбутніх лікарів компетенції у питаннях причин і наслідків професійного вигорання, діагностики, корекції та реабілітації проявів СЕВ, навчання методів самодопомоги.

5. Kronemyer B. Physician burnout not a "thing" / B. Kronemyer // Dermatology Times. Clinical Insights That Expand Expertise and Advance Practice. - 2018. Vol. 39, No. 11. URL : https://www.dermatologytimes. com/worklife-balance/physician-burnout-not-thing.

6. Medscape National Physician Burnout \& Depression Report 2018. Medscape. URL : https://www.medscape.com/ slideshow/2018-lifestyle-burnout-depression.

7. Prevalence of burnout among physicians: A systematic review / L. S. Rotenstein, M. Torre, M. A. Ramos [et al.] // JAMA. - 2018. - Vol. 320, No. 11. - P. 1131-1150. DOI:10.1001/jama.2018.12777. 


\section{References}

1. Bulakh, V.P. (2015). Syndrom profesiinoho vyhorannia yak skladnyi patofiziolohichnyi fenomen [Professional burnout syndrome as a complicated psychophysiological phenomenon]. Medsestrynstvo - Nursing, 4, 47-51 [in Ukrainian].

2. Raigorodskii, D.Ya. (2005). Prakticheskaya psikhodiagnostika. Metodiki i testy [Practical psychodiagnostics. Methods and tests]. Samara: "BAKhRAKh-M" [in Russian].

3. Yureva, L.M. (2004). Professionalnoye vygoranie u meditsinskikh rabotnikov: formirovanie, profilaktika, korrektsiya [Professional burnout in health care workers: formation, prevention, correction]. Kiev: Sfera [in Russian]. 4. (2018). Yak vporatys z emotsiinym vyhoranniam medychnym pratsivnykam [How to cope with emotional burnout for healthcare staff]. MOZ Ukrainy - Ministry of Health of Ukraine. Retrieved from: http://moz.gov.ua/ article/for-medical-staff/jak-vporitis-z-emocijnimvigorannjam-medichnim-pracivnikam [in Ukrainian]. 5. Kronemyer, B. (2018). Physician burnout not a "thing". Dermatology Times. Clinical Insights that Expand Expertise and Advance Practice, 9, 11. Retrieved from: https://www.dermatologytimes.com/worklifebalance/physician-burnout-not-thing.

6. (2018). Carol Pekham Medscape National Physician Burnout \& Depression Report. Retrieved from: https:// www.medscape.com/slideshow/2018-lifestyle-burnoutdepression.

7. Rotenstein, L.S., Torre, M., Ramos, M.A., Rosales, R.C., Guille, C., Sen, S., \& Mata, D.A. (2018). Prevalence of burnout among physicians: A systematic review. JAMA, 320, 11, 1131-1150. 